\title{
Advertising and Methodology What advertising has to teach us about (the study of) Thai Buddhism Part two
}

\author{
Miloš Hubina
}

https://doi.org/10.14712/25704893.2017.10

\begin{abstract}
In this paper I make proposals regarding further advances in the studies of Theravada Buddhism along the lines suggested by Justin McDaniel in his The Lovelorn Ghost and the Magical Monk (2011). The benefits of McDaniel's approach lie in his de-emphasis of doctrinal tradition and his focus on local frames of reference in explaining Thai Buddhism. Its faults lie in a disregard for the developments outside the socio-cultural paradigm. I argue for the integration of socio-cultural and naturalist approaches to the study of religion. Balancing the over-accentuation of the explanatory power of either socio-cultural or cognitive concepts, such integration would also permit a move from the socio-cultural metaphorical models to causal and more controlled explanations of religious phenomena.

I illustrate my suggestions through an example of a Thai wat (shrine/monastery). One of these suggestions, implied by the de-emphasis of the doctrinal tradition, is to recognize the predominantly advertising and ritualistic function of wats' visuals, effigies, and architecture rather than reading them as symbolic expressions of doctrinal tenets.
\end{abstract}

Keywords: Thailand, Buddhism, Theravada, Advertising, Wat, Shrine, Cognitive Science of Religion

\begin{abstract}
Abstrakt: Ve svém článku se pokouším o další rozvinutí metodologie studia thajského buddhismu navrhnuté Justinem McDanielem $\mathrm{v}$ jeho knize The Lovelorn Ghost and the Magical Monk (2011). Pozitivem prístupu vypracovaného McDanielem je, že ve snaze osvětlit charakter thajského buddhismu přesouvá důraz ze studia doktrinální tradice na prvky lokálního kontextu. Negativem pak je opomíjení výsledků bádání a teoretických postupů souvisejících bezprostředně s jím navrhovanými řešeními, formulovanými však mimo standardní socio-kulturní paradigma. Na príkladu situace $\mathrm{v}$ thajském watu (klášter/ svatyně) Thámai ilustruji možnou integraci socio-kulturních a naturalistických prístupu, která umožnuje postup od užitečných metafor socio-kulturních modelů ke kauzálním a více kontrolovatelným vysvětlením náboženských fenoménu a vyvažuje přeakcentovávání explanační síly jak sociokulturních, tak kognitivních konceptů. Jedním $z$ důležitých motivů, které bezprostředně vycházejí z metodologického odklonu od důrazu na doktrinální stránku při vysvětlování “žité” náboženské tradice, je potřeba rozeznat primárně reklamní a rituální charakter thajských buddhistických vizuálů, architektury a podobizen, které tradičnější prrístup interpretuje jako symbolické vyjádření článků doktríny.
\end{abstract}

Klíčová slova: Thajsko, buddhismus, theravada, reklama, wat, svatyně, kognitivní religionistika

Received: 17 March 2016, Accepted: 21 April 2016 Published online: 13 November 2017

Miloš Hubina, Ph.D., College of Religious Studies, Mahidol Univerisity, Thailand.

E-mail: miloshubina@yahoo.com

(C) 2017 The Author. This is an open-access article distributed under the terms of the Creative Commons Attribution License (http://creativecommons.org/licenses/by/4.0), which permits unrestricted use, distribution, and reproduction in any medium, provided the original author and source are credited. 


\section{Where the wat begins?}

Wat Thāmai, rebuilt in 1989 from an abandoned wat into a prosperous and popular site, is located $60 \mathrm{~km}$ West of Bangkok in Samut Sakhon province, and concentrates the divergent elements of Thai Buddhism scattered across more than 40000 Thai monasteries. In condensed form it reveals religious sentiments, and values of a large sample of Thai population.

The Thai wat is typically thought of as an enclosed compound whose high roofs, stüpas, prangs, or elevated geographical position announce its presence far beyond its walls.

Wat Thāmai, remote from Bangkok's historical hot-spots and urban centers, makes its presence noted broad and wide by means of car-stickers (pic. 1), billboards (pic. 2), a web page (http://wattamai.org/), a Facebook profile, and publications. For practical reasons I will limit my discussion to the most direct and accessible forms of advertising which don't require an active search on the part of targets. This will leave aside web-pages, books, pamphlets and journals.

The most visible advertising material is car-stickers with the name of the wat. In the streets of Bangkok one has a chance to meet a car with such a sticker as often as about once per hour. Some other wats e.g., wat Phutthavāt, wat Khunjan, or wat Thākhrabt have also adopted this advertising strategy but with a much lesser presence. Luang Pī So (หลวงพี่สอ), a monk responsible for advertising at wat Thāmai told me that the stickers originally identified cars belonging to the wat. Later, on request of frequent visitors, they started producing them on a large scale.

In their capacity to make the wat visible far beyond its actual location, the trifling stickers are the equivalent of towering stüpas, shrines, and effigies. Unlike the monuments, however, they have to stimulate the drivers' active participation in what

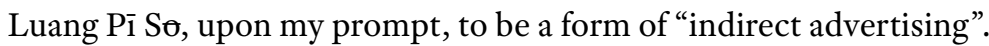

The appeal rests in the stickers' protective function. They are blessed (T. athitthānjit, อธิษฐานจิต) by the abbot Luang Pī Uthēn (หลวงพื่อุเทน) though, unlike amulets and other more powerful objects, they are not subject to the T. pluksēk (ปลุกเสก) ritual charging them with magical power (T. sagsit, ศักดิ์สิทธิ์). Some informants expressed the belief that the protective blessing helps them to drive safely. More often, however they responded echoing the message written on the banner next to the shop where the stickers, amulets, religious statues and other objects can be obtained. ${ }^{1}$ It reads: "Wherever adherents/disciples (T. lüksit, ลูกศิษย์) of wat Thāmai see the sticker wat Thāmai they behave to each other with love and loving kindness, and help each other." (pic. 3) People expressed the belief that attached to cars the stickers create a community among anonymous drivers who are then more likely to help each-other, show respect, and exhibit less aggression in driving. To be sure, the line between a magical and non-magical view of the same practice is often blurred and people can

1 The stickers are kept in a small basket on the counter. No price is given; anybody can take them and leave a small donation, if they wish, in a donation-box next to the counter. 
entertain both views simultaneously. At any rate, these were the only answers I have been getting through dozens of informal talks and casual questions.

Let me now delineate the tentative "stabilizing dint" of the practice.

According to general cognitive theory of magical thinking, in the absence of an obvious causal link between magical action and its presupposed effect, the mind spontaneously seeks "weak" causal connections. These consist of perceptual associations of contiguity, similarity, and force dynamics ${ }^{2}$ and are organized through various "image schemata". ${ }^{3}$ The image schemata, pre-conceptual structures ordering our perceptual experience, include the "object - container" schema. ${ }^{4}$ The structure of these intuitions makes it feel natural that a substance - "magical power" (T. sagsit, ศักด์สิทธิ์) - can be transmitted via physical contact (contagion, continuity) ${ }^{5}$ from its source (a monk) to a "container" (sticker) and then further to a car. This is not to say that we are bound to believe in the efficacy of particular practices or magic in general. The point is that magical practices structured in accord with these intuitions will feel more "natural" and believable than those which defy them (e.g., magician inserting his own, instead of the victim's, hair into the voodoo doll).

As for the non-magical explanation of the stickers' attractiveness, the general human tendency to join groups, "groupishness", ${ }^{6}$ encoded in our cognitive architecture explains the human proclivity for forming groups with a variety of membership criteria.

Both of these are general theories which sufficiently explain magical thought and the general human tendency to form groups. They, however, do not suffice to explain the recruitment of these structures in this particular context. To answer McDan-

2 Things once connected may mutually influence each other even after disconnection (e.g., a voodoo doll containing hair, nails, or another part of the intended victim's body), like affects like (e.g., pouring water may cause rain), the more effort invested the more probable or greater the effect will be.

3 For a thorough description of magical thinking see Jesper Sørensen, "Charisma, Tradition, and Ritual: A Cognitive Approach to Magical Agency", in Harvey Whitehouse and Robert M. McCauley (eds.), Mind and Religion: Psychological and Cognitive Foundations of religion, Lanham: Altamira Press 2005, p. 167-186; and Jesper Sørensen, A Cognitive Theory of Magic, Lanham: Altamira Press 2007, passim.

4 E.g., we expect that the soul, or mind, although immaterial is in the body. Image schemata orient our intuitions about the words according to our tactile experience. Our language reflects them when we for example say that we are in troubles (object-container schema), etc.

5 Kumer explains that contiguity is the main cue for causality. As he says "contiguity is a major cue of weak cause detectors because, without stronger knowledge concerning what events can or cannot have been the cause of a particular event, the number of candidate environmental events that occurred (even in the preceding five minutes before the effect) is too large to be analyzed from an acceptable number of repetitions." Hans Kumer, "Causal Knowledge in Animals", in Dan Sperber, David Premack and Ann J. Premack, Causal Cognition: A Multidisciplinary Debate, Oxford: Clarendon Press, New York: Oxford University Press 2002 (first published 1995), p. 26-36.

6 See Matt Ridley, The Origins of Virtue: Human Instincts and the Evolution of Cooperation, Penguin Books 1996, p. 39 ff.; PAsCal Boyer, Religion Explained: The Evolutionary Origins of Religious Thought, New York: Basic Books 2001, p. 126; JonAthan Haidt, The Righteous Mind: Why Good People are Divided by Politics and Religion, New York: Vintage 2012, chapter 9. 
iel's questions - Why is this practice popular (or likely to be popular) among Thais? Why is this wat popular? We need to attend to the cultural aspect of the stabilizing dint. It is relatively easy to find religious practices isomorphic with the magical explanation of the stickers' protective power. The craze for "lucky" numbers on cars' registration plates is one example. Another is the practice of attaching the stickers "This car is red" (or of any color determined by a specialist, usually a monk, as auspicious for the car) to cars of a non-corresponding color. It is believed that the sticker substitutes for a much more expensive re-painting of the vehicle. These and similar phenomena echo more traditional apotropaic routines of drawing protective yantras on objects of utility, which nowadays includes the cars. (pic. 4) The practices thus reinforce each other as each of them derives part of its stability from belonging to an established belief. This cluster is in turn nested in the broader cultural system and stabilized via correspondence with specific cultural values and practices. The nesting also permits the non-religious explanation of its practices.

The symbolic indication of social status, institutional affiliation, or connection to centers of power has been identified by anthropologists and psychologists as a part of Thai protective social strategy. ${ }^{7}$ It includes massive purchasing of real and fake brand apparel and accessories, popularity of registration plates with the EU flag, uniforms, or jackets with logos and badges. Much more visible than in Europe are small emblems attached to the inside of a car's window signaling the driver's affiliation to a specific institution. A few years ago the Nazi swastika and other Nazi motifs were popular, attached to a vehicle or worn printed on a t-shirt. Though less visible today, they haven't disappeared utterly despite a criticism in the media stimulated by the Westerners' reactions rather than a genuine domestic knockback. (pic. 5)

The protective function of these signs and symbols is achieved by turning the person from a nebulous social unit to a recognizable T. khon $m \bar{\imath} s \bar{\imath}$ (คนมีสี). Engel defines "khon $m \bar{\imath} s \bar{l}$ (people who have colors)" as an expression for "people who are set apart from the general population because they wear uniforms, such as the police, military, or other government officials" ${ }^{8}$ but as a principle the concept stretches far beyond these groups. If no real or feigned association with a prestigious institution is

As Mulder observes, "Even in the most casual encounters, people soon want to find out who the other person is in terms of his social rank, and consequently, their relative social distance: What is the work he does? To what institution or group does he belong? What rank does he hold? Is he rich or poor? Has he studied, and where?” Niels Mulder, Everyday Life in Thailand: An Interpretation, Bangkok: Duang Kamol 1979, p. 68, emphasis mine. Or elsewhere "Any attributes of status that one can muster are brought to the fore to demonstrate relative rank and position, ranging from nuances of speech to the displaying the insignia of rank, from one's dress to a style of life. It appears that one's security is highly dependent on the symbols and material resources that one can muster, everybody is striving to be พี่ (phii, 'older brother'), phuujaj, or เจ้านาย (cawnaaj, 'boss'). MuLDER, Everyday Life in Thailand, p. 70.

8 David M. Engel and Jaruwan D. Engel, Tort, Custom, and Karma: Globalization and Legal Consciousness in Thailand, Stanford: Stanford University Press 2010, p. 173. 
possible, the Nazi swastika or other symbols of dangerous naked power wielded by hooligans, T. naklēng (นักเลง), do the same job. ${ }^{9}$

McDaniel is right in marking out security as a motive associated with religious behavior. Indeed, the arguments to the effect that "feelings of vulnerability to physical, societal, and personal risks are a key factor driving religiosity" (Norris, Inglehart 2004: 4) has been made repetitively and from various theoretical perspectives in the history of religious studies. But security seems to be a universal, ${ }^{10}$ not uniquely Thai value. It can also mean different things in different contexts. As Norris and Inglehart also observe, " $t]$ he wide range of dangers means that the concept of human security can become so broad and overloaded that it can lose all coherence and practical utility, as well as becoming difficult or even impossible to gauge with a single composite measure. Nevertheless, the core idea of human security, irrespective of the specific nature of the risks, is one that is widely recognized as important to well-being, and we regard the absence of human security as critical for religiosity."

Given this universality and large scale of domains, unless a range of dangers, insecurities, and ways of dealing with them endemic to Thai reality are specified, "security" cannot tell us anything about Thai Buddhism in particular. McDaniel fails to provide any such specifications and all his values are presented in the same way.

Besides enthusiastic and advertising descriptions of "smiling people" produced by tourist authorities, also many official documents on "Thainess", reflecting their political agenda, present an idealized form of Thai culture and a prescriptive rather than

9 "The marginal persons follow a different strategy, and their power inspires fear rather than respect. [...] They present themselves as naked power, to be feared and respected like malicious spirits, and in everyday life it is recommended to stay out of their way or to buy them off" (MuldER, Everyday Life in Thailand, p. 77). Mulder analyzed both the Thai social structure and the structure of supernatural beliefs in terms of two main forms of power recognized by Thais. One is strictly moral T. khun (คุณ) - goodness, the other amoral T. dèt (เดช). He emphasizes that khun is to be found in the family circles while "[i]n the overall Thai social process a person equates with his status and relative position of power, from which he derives intense satisfaction. There is no morality or goodness implied although they may be present; it is rather the show of being superior, powerful, and prestigious that matters." (Mulder 1979: 71) In the public sphere or "third person interaction" as Mulder calls it "the attributes of power seem to predominate the interaction: one wards it off by polite (สุภาพเรียบร้อย) and humble (ถ่อมตัว) behavior and expects that the powerful expression of the other is so subdued" (Mulder 1979: 75). These concepts of power also inform Ockey's political analysis. He identifies "two broad styles of traditional leadership: the phudi, based on khunna [khun], or virtue, and the nakhleng, based on decha [dèt], or power" (JAMEs Ockey, Making Democracy: Leadership, Class, Genders, and Political Participation in Thailand, Chiang Mai: Silkworm Books 2004, p. 15). While a phüdī (ผู้ดี) (good man) is considerate, compromising set firmly in and respecting the social structures, a nakhlēng (นักเลง) is a maverick, a hooligan executing his will through his personal rather than institutionally vested powers.

${ }^{10}$ See Shalom H. Schwartz, "Universals in the Content and Structure of Values: Theoretical Advances and Empirical Tests in 20 Countries" (online), Advances in Experimental Social Psychology 25 (1992), accessed May 2016, available online at http://kodu.ut.ee/ cect/teoreetiline\%20 seminar\%2023.04.2013/Schwartz\%201992.pdf.

${ }^{11}$ Pippa Norris, and Ronald Inglehart, Sacred and Secular: Religion and Politics Worldwide, Cambridge, New York: Cambridge University Press 2004, p. 4. 
descriptive system of Thai values. ${ }^{12}$ Still, some politically motivated documents do aim beyond merely inculcating desirable values. The document issued by the National Security Council in 1976, for example, identifies both the negative and positive Thai characteristics in an attempt to create a basis for the "development of national identity". The list includes: love of freedom; loyalty towards the monarchy; respect of religion; dislike of violence; assimilation; coordination of interests; elevation of money, power and knowledge, seniority, generosity, forgiving, fun and risk-taking; belief in the supernatural; doing whatever one pleases; upholding of tradition and custom; a Buddhist contentedness; and an attitude supportive of non-interference in other people's affairs."'13

Turning to academic writings, Khrtakaew in his "Thai Social Characteristics" mentions wealth, power, seniority, naklēng spirit (naklēng is "hooligan", "rouge", T. huamai, หัว ไม้), social status, generosity, gratitude, wisdom, propriety in etiquette. ${ }^{14}$

Suntaree Komin, in what is still the most complex analysis of Thai social values and behavioral patterns, ${ }^{15}$ identifies nine value clusters according to their relative significant position in the Thai cognitive system: 1. ego orientation, 2. grateful relationship orientation, 3. smooth interpersonal relationship orientation, 4 . flexibility and adjustment orientation, 5. religio-psychical orientation, 6. education and competence orientation, 7. interdependence orientation, 8. fun-pleasure orientation, 9. achievement-task orientation. ${ }^{16}$

Though the value of safety doesn't appear explicitly on her list, Komin discusses it in the context of religious-psychical orientation. She notes a high correlation between the concept of "national security" and "religion": "An inspection of these two values shows a correlation of +32 , the highest correlation of religion with any variable." She also notes that "for the Thai, National security is the top concern and more so in the rural areas than in Bangkok." ${ }^{18}$ Less specifically she discusses the issue of inter-

${ }^{12}$ Recently the National Council for Peace and Order issued the list of the twelve Thai values to be nurtured (ค่านิยมหลักของคนไทย 12). These are actually twelve clusters of values and include: loving the nation, religion and the monarchy; honesty, sacrifice, patience; gratitude to parents and teachers; continuous learning - Institutionalized or self-learning; ethics, honesty, concern about other people; the correct understanding of the principles of the democracy with the king as the head of state; discipline, law-abiding, respect to superiors, and others. The list has been then published on webpages of many governmental institutions. See "The Twelve Thai Values" (online), Ministry of Natural Resources and Environment, accessed February 2016, available online at http://www.mnre.go.th/ewt_news.php?nid=3230.

${ }^{13}$ Determining factors of national ideology, in National Ideology [Udomkan khong chat, อุดมการณ์ ของ ชาติ],1983, p. 21-22; quoted in MichaEL K. Connors, Democracy and National Identity in Thailand, New York, London: RoutledgeCurzon 2005, first published 2003, p. 138.

${ }^{14}$ Phaithun Khruagaew Na Lamphūn, Lagsana Sangkom Thai, Nāi Yōt Ying Sōphon Phū Phim Phū Khōsanā1975 , p. 69-79.

${ }^{15}$ Komin's study is based on data derived from two national samples, 1978 with a total of 2469 samples and 1981 with 2149 samples, collected via multistage sampling technique. SUnTAREE Komin, Psychology of Thai People: Values and Behavioral Patterns, Bangkok: NIDA 1990 p. 290.

${ }^{16}$ Komin, Psychology of Thai People, p. $160 \mathrm{ff}$.

${ }^{17}$ Komin, Psychology of Thai People, p. 133.

${ }^{18}$ Komin, Psychology of Thai People, p. 143, emphasis original. 
personal and social insecurity. It appears passim in her study but doesn't receive concentrated attention. Starting with the early serious studies of Thai society in the late fifties scholars have emphasized the insecure nature of social relationships and overall flexible, unpredictable, non-committing, and opportunistic Thai behavior. ${ }^{19}$ General distrust from Thai people towards their legal system and unreceptive police described by Engel \& Engel $^{20}$ underlines this insecure quality of an environment where weak institutionalized protection and law enforcement makes the whims of the powerful an unfathomable threat. At the present, Thailand occupies the $125^{\text {th }}$ position (out of 163) on the list of the Global Peace Index ranked with the most peaceful countries on top. In terms of Societal Safety \& Security it occupies $131^{\text {th }}$ position. ${ }^{21}$

The Thai value system seems to strongly contribute to this social insecurity. Go Sawatdipanit ponders that in his personal opinion "the most prominent characteristic of Thai people is acting feely." ${ }^{22}$ Mole, ${ }^{23}$ referring in this respect also to David Wilson's Politics in Thailand, ${ }^{24}$ sorts out the Thai's “[d]esire to be free of supervision" as a commonly discussed characteristic Thai quality. In the Komin's study the value figures as "flexibility and adjustment orientation" or "flexibility over principle and ideology". ${ }^{25}$

This "freedom" is closely related to the elevated status of "power" in the Thai value system since power augments the opportunity to "do whatever one pleases". As will become clearer presently, the ego orientation, naklèng spirit, and social status values are understood in the context of the two values. In actual fact, power-structures guide most of Thai social dynamics which, floating freely over institutional structures, are fueled by individuals' differential capacities to bestow or deny benefits on the basis of personal rather than institutional criteria.

Mulder makes the concept of power central to his analysis of Thai society and religion, and in both areas it proves a useful heuristic tool. Many Thai sociologists make the same emphasis. ${ }^{26}$ In my further discussion of the Thai value system and behavioral patterns I will draw mainly on his and Komin's studies.

The proverbial Thai smooth and highly formalized interpersonal relationships often stand, as both scholars concur, as the only buffer between one and the unchecked exercise of power in the highly unpredictable world. In Mulder's own words:

${ }^{19}$ See Komin, Psychology of Thai People, p. 197.

${ }^{20}$ David M. Engel, and Jaruwan D. Engel, Tort, Custom, and Karma: Globalization and Legal Consciousness in Thailand, Stanford: Stanford University Press 2010, 190 p.

21 "Global Peace Index 2016" (online), Institute for economics and Peace, accessed June 2016, available online at http://static.visionofhumanity.org/sites/default/files/GPI\%202016\%20Report_2.pdf, p. $9,111$.

${ }^{22}$ Gē SAWATPHĀNIT, "Lagsana Sanghom Thai”, in PHANĒK ISARA SANGKOM VITHAIĀ LAE MĀNUSAIAVITHAIĀ MAHĀVITHAIĀLAI THAMMASĀT, Rāingān Gān Sammanā Thāng Vichāgān Ruang Lagsana Sangkhom Thai, HJG. Gān Phim Phranakhon, 1979, p. 151.

${ }^{23}$ Robert L. Mole, Thai Values and Behavior Patterns, Rutland: Charles E. Tuttle Company 1973, p. 51.

${ }^{24}$ David A. Wilson, Politics in Thailand, Ithaca: Cornell University Press 1963.

${ }^{25}$ Komin, Psychology of Thai People, p. 197-207.

${ }^{26}$ See Mulder, Everyday Life in Thailand, p. 61. 
"Behind the smile of smooth interaction we will often find insecurity and the feeling of kreengklua [fear, awe ...]. [P] ersons meet with each other as with potentially harmful forces that need to be subdued by nice, polite, and pleasant behavior. The ritual smile and presentation are the primary (and often ultimate) defense mechanisms to deal with each other."27

Elaborating further on this point he brings to light the connections between the role of social presentations, the ego, social status and insecurity:

"Some people identify highly with their social performance, invest heavily in presentation, and are consequently highly vulnerable in their presentation. Status anxiety and insecurity would therefore seem to be endemic, eventually coupled with feelings of inferiority and of revenge and vindication. The powerful element of presentation being that important and so potentially dangerous, one may also expect deep seated feelings of suspicion, fear, and techniques to avoid confrontation with power: kreengklua, kreengcaj, and non-commitment becoming deeply internalized attitudes." 28 Though tempering Mulder's claims that Thais' "'pleasant' presentation is a defense mechanism generated mainly from fear", ${ }^{29} \mathrm{Komin}$ also asserts that "[t]he Thai are first and foremost ego oriented" and that "[t]his ego orientation is the root value underlying various key values of Thai." ${ }^{30}$ She then draws a portrait of an unstable inter-individual environment in which Thais "can be easily provoked to strong emotional reaction, if the 'self' or anybody close to the 'self' like one's father or mother, is insulted" and doesn't fail to mention the "countless number of examples in the media, where people can readily injure or kill another person for seemingly trivial results." Her description thus reveal an emotional landscape where, as in Mulder's and others accounts, the symbolic regulation of behavior serves as a buffer against irrational outbursts whenever one's "ego" is threatened. Criticizing the Buddhism-explains-it-all approach she goes on to say that "[ $t]$ his is why many analyses using Buddhist influence to explain about the Thai being so gentle, ever-smiling, non-aggressive, affable and have high tolerance for uncertainty, fail to explain the sudden emotional outburst of Thai behavior." ${ }^{32}$

The outbursts provoked by a threat to the socially constructed "ego" are ruptures in otherwise neatly controlled behavioral patterns, sensitized to social hierarchy, constantly reading the surrounding power-structures and what do they mean for one's "ego".

It should be noted that the social and religious practices discussed above are not designed to reduce the overall uncertainty by making the environment more transparent, predictable, and rule-based. With the high tolerance to uncertainty among the Thai people, the focus is on protecting oneself through mustering as much power

${ }^{27}$ Mulder, Everyday Life in Thailand, p. 73.

${ }^{28}$ Mulder, Everyday Life in Thailand, p. 82.

${ }^{29}$ Komin, Psychology of Thai People, p. 17.

${ }^{30}$ Komin, Psychology of Thai People, p. 161.

${ }^{31}$ Komin, Psychology of Thai People, p. 161.

${ }^{32}$ Komin, Psychology of Thai People, p. 162. 
as one can in a fundamentally uncertain world. Of course, the fact that the power one wields is most functional in social situations when it is recognized but doesn't have to be exercised, boosts the importance of symbolic means which indicate one's power and status.

As suggested above, the "ego" is strongly dependent on appearance and symbolism. Komin notes the general Thai tendency to prefer "form over content" 33 and maintains that one's ego is identical with façade, "the face", and is very sensitive. ${ }^{34}$ She warns that "[t]o make a person lose "face", regardless of ranks, is to be avoided at all costs. ${ }^{{ }^{35}}$ Mulder, speaking in one voice with Komin, puts in plain words that "[p]resentation is one's social being, at which one is measured, more according to qualities of conformity and power than of knowledge, integrity or morality." ${ }^{36} \mathrm{He}$ also shows how the fragility of the symbolically construed ego piles on the overall insecurity of the environment:

"That presentation, or face, however, is easily insulted. Like any other spirit, power wants to be kreengklua and to be shown honour and respect. If not, power may turn vengeful, and revenge for insult of power and position is highly endemic to Thai society, for which we only need to read the daily newspaper, to reflect upon the rich vocabulary to express feelings of hatred and revenge, and the ease with which competitors are killed and done away with." (Mulder 1979: 75-76) As I am writing these lines the Channel 3 is presenting news about a senior lecturer from Phranakhon Rajapath University (มหาวิทยาลัยราชภัฏพระนคร) shooting dead his two colleagues in response to what he called offenses and wrong-doing.

Overall, Thais are born into a highly formalized environment where a successful and mentally satisfying life is conditioned by continuous detection of, and self-adjusting to, symbolic representations of power. Not only powerful and respected personages are shown respect. Respect is paid, by a slight bow with palms joined in front of one's chest (T. wai, ใหว้), also to the statues of the Buddha, deities, kings, omnipresent spirit-houses or distant roofs of a wat. This is not to say, however, that people live in constant fear, bowed down under an ominous shadow of power. Exactly because the power is universally acknowledged and sufficiently indicated to prevent a confrontation, it typically assumes a coercive form only in extreme and foreseeable situations. As with the Thai approach to ghosts, captured in the popular saying "you may not believe, but never offend", it is more a matter of constant vigilance rather than immediate confrontation.

Wat Thāmai stickers resonate with this dominant cultural pattern of protective association through powerful symbols. The protective power of symbols in this case doesn't depend on any particular doctrinal tenet or necessarily "religious" - i.e., "related to extra-empirical entities" - beliefs. It draws on overall cultural recognition of

\footnotetext{
${ }^{33}$ Komin, Psychology of Thai People, p. 226.

${ }^{34}$ Komin, Psychology of Thai People, p. 162.

${ }^{35}$ Komin, Psychology of Thai People, p. 162.

${ }^{36}$ Mulder, Everyday Life in Thailand, p. 83.
} 
the power of symbols, re-affirmed everyday through the character of interpersonal relations, socio-political practices and, ultimately, the very nature of one's "ego".

\section{Karma and Billboards}

Large billboards and smaller posters and banners are other uses of media to extend a wat's presence beyond its walls. In Bangkok, five paid billboards advertise wat Thāmai's activities, usually one month in advance. A freelancer hired to make their design draws on the abbot's suggestions, who also decides about the billboards placement. No part of the process is supervised by a higher ecclesiastical authority. In addition to these temporary billboards a few permanent installations produced and managed by the wat's followers can be seen in the streets of Bangkok. One of them is hanging from a three-story building at the busy Krathum Baen intersection. (pic. 6) It says "The place of Siamese belief - wat Thāmai". The word "belief" is expressed by Thai word "satth $\bar{a}$ " (ศรัทธา) (Pali. $s a d d h \bar{a}$ ) typically denoting the attitude of trust in the Buddha's teaching while blind faith or superstitious beliefs are referred to as "khwāmchua" (ความเชื่อ). The statues represented in the pictures announce the objects of this belief. They include the Buddha, the "Hindu" gods Ganesa and Shiva, the Chinese Guan Ying, and the demon Rāhu (T. Phra Rāhū, พระราหู). The composition also contains a picture of a senior Theravāda monk, Luang Pī Rung (หลวงพี่รุ่ง), teacher of the present abbot, the uposatha hall, and - aligned along the bottom edge - a group of young, good-looking Thai movie-stars. The message is clear - this panoply of supernaturals, personages and values they represent doesn't refer to a cultic movement, a lower form of a higher tradition but to complex practices and aspirations of mainstream Thai Buddhists.

Banners along the road to the wat's main entrance, posted in the adjacent parking lot or inside the wat provide a straight insight into the values directing, at least from a significant part, Thai religious life. On the road, the banners announce "strength", "wealth", and "prosperity"; those in the parking lot feature Thai movie-stars, magical amulets produced in the wat, and words announcing the benefits for those who contribute to the building the wat's bōt via purchasing ${ }^{37}$ them. These benefits include fame, safety, loving kindness (P./T. mettā, เมตตา), wealth, success in business or avoiding danger and harm. ${ }^{38}$ (pic. 7) Similar inscriptions can be seen on the outside and inside walls of the hall dedicated to the worship of demon Rāhu. They read:

${ }^{37}$ The correct word is "renting" (T. chau, เช่า) since monks cannot engage in merchandise. This linguistic trick is yet another illustration of the practical relevance of symbols and symbolic proclivity characterizing Thai culture. Though in many wats monks themselves sell the amulets, the actual selling is done by a layman in wat Thāmai.

${ }^{38}$ For a more rounded account, the pictures of movie-stars worshiping religious effigies, paying respect to the abbot or cleaning toilets at the wat should also be mentioned as these express the values of lowliness and modesty vis-à-vis religion. 
"happiness", "avoiding the danger”, "safety”, "prosperity”, "possessing”, "success and well-being”, "virtue”, "wealth".

An interesting expression of the practices related to these values is represented by the statue of Buddha sitting in the lotus position with his eyes closed, covering his ears. (pic.8) The effigy defies Theravāda iconographic conventions; the position is not listed among the forty standardized positions to depict the Buddha compiled by Prince Paramanuchit Chinorot (พระปรมานุชิตชิโนรส) during the third reign of the Chakri dynasty (A.D. 1824-1851) ${ }^{39}$ or in an extended catalogue provided by L. I. Matics in her Gestures of the Buddha, which includes 107 gestures.

Luang Pì Uthēn, the abbot, has stated that the effigy, referred to as Phra Pit Hū (พระปิดหู) - the Buddha Covering his Ears, or Phra Pit Khrø (พระปิดเคราะห์) - the Buddha Eliminating Khro, doesn't depict any event of the Buddha's life, the typical point of reference of traditional Theravāda iconography. The symbolic meaning of the statue is to eliminate, unlock, cut off, ward off, dilute bad luck, stars, fate or bad kam$\mathrm{ma}$ (khro, khrøgam, เคราะห์, เคราะห์กรรม) and "atoning for all wrongdoings". ${ }^{40}$ As one informant explained - "If the Buddha doesn't see it, it doesn't exist". Yet the statue is not a symbolic Berkeleyan ontological statement but an autonomous expression of an important, if not the primary, focus of the religious activities and sensibilities of the place. The abbot is famous for his astrological predictions, a practice which the monastic code (P. Vinaya) classifies as a violation of rules entailing initial and subsequent meetings of the Community (P. sanghädisesa). ${ }^{41}$ Also "[p]erforming ceremonies to counteract the influence of the stars" falls under the same category. ${ }^{42}$

Heedless of the canonical dictum, the astrological charts, banners explaining palmistry are ubiquitous here and the Chinese zodiac signs have found their way even to the wat's uposatha hall. To get the horoscope reading one has to arrive at the wat before 8 a.m. to pick up the queue number for that day. Signs advertising rituals counteracting the influence of the stars and other adverse powers permeate the place. It would be a mistake to see all this as an individual rebellion against the rules. Palmistry, horoscopes, production of magical amulets, potions, tattoos and other practices of "lower arts" pervade Thai wats.

The laxity with regard to this and others monastic rules is typically excused, whether by monastics or laypersons, as acts of help (T. chuai, ช่วย). Monks sell protective amulets to "help" to those who believe in their efficacy. The abbot built the pavilion

39 The list is not an absolute authority but deviations from it are very rare.

40 The statue, as with virtually every object and practice of Thai wats, also has its more doctrinal interpretation. The abbot has explained to me that the closed eyes and covered ears of the Buddha symbolize that the doors through which mental defilements (P. kilesa, T. gilèt กิเลส) enter are closed. But none of my informants ever even alluded to this interpretation. Also, as the popular name of the statue suggests, this is not how the effigy is understood.

41 "Sañghādisesa are classified as heavy offenses (garukāpatti), both because of the seriousness of the offenses themselves and because the procedures of penance, probation, and rehabilitation are burdensome by design, not only for the offender." Thānissaro, The Buddhist Monastic Code: The Pātimokkha Training Rules Translated and Explained, The Mahāmakuta Educational Council 1993, p.136.

42 Thānissaro, The Buddhist Monastic Code, p. 133-134. 
for worship of the demon Rāhu to help those who want to worship him. ${ }^{43}$ Along with this, wrong decisions, and inappropriate or criminal acts are, in the wider context of Thai society, stereotypically amended as motivated by a wish or need to help someone and the appeal is typically heard. I have no intention to judge the genuineness of this attitude. I am concerned here with a powerful concept which allows people to easily cross the established institutionalized lines, benefit from such transgressions, or ameliorate the graveness of wrongdoings. The concept of "help", resonant with the ego-orientation, elevated status of power and the "flexibility over principle and ideology" overrides institutional guides.

As I have mentioned above, there is a strong tendency in contemporary scholarship to explain away these values and practices, including their advertising, as "prosperity" or "commercial” Buddhism, (T. phuttha phānit, พุทธพาณิชย์) ${ }^{44}$ symptomatic of " $t$ ] he commercialization of Thai Buddhism [which] is perhaps the single most influential concept defining Thailand's multiple forms of prosperity religion." ${ }^{45}$

Kitiarsa proposes to see " $[p]$ huttha phanit as the dominant form of commodification of Thai Buddhism" and "a recently-emerging threat to established Buddhism and its institutions." ${ }^{46}$

He also claims that "Thai Buddhism has embraced, rather than rejected or estranged itself from, modernizing and secularizing forces. Thai Buddhist practices are redefined and redirected towards more materialistic and worldly goals in order to situate itself in the hybrid religio-cultural environments. The commercialization of Thai Buddhism (phuttha phanit), arguably the Thai variant of Comaroff and Comaroff' ${ }^{37}$ occult economy, shows contemporary needs as a key factor in how religion has maintained its strongholds in modern Thai life. Despite criticism and outrage from the Thai middle-class intellectuals and a segment of the Sangha, the cult of the phuttha phanit has profoundly shaped the rationality and sensibility of 'being worldly-engaged Buddhists' to the Thais. Pushed by the large-scale merit making industry, the prosperity cult of phuttha phanit represents a religo-cultural space where popular Buddhism has converged with the market economy, consumerism, and the quest for personal and cultural identities." ${ }^{38}$

I don't think the commodification thesis does justice to the phenomenon. Contrary to the claim that this commodification is a (post-) modern phenomenon stands

${ }^{43}$ S. Sutthipan, Gae Gam Phon Thuk Ānisong Haeng Satthā Jāk Luang Pū Rung Thung Phra Ājān Uthèn, Borisat Sathāpon Buk Jamgat 2009, p. 87.

${ }^{44}$ See also Justin T. McDaniel, The Lovelorn Ghost and the Magical Monk, New York: Columbia University Press 2011, p. 190.

${ }^{45}$ Pattana Kitiarsa, "Buddha Phanit: Thailand's Prosperity Religion and its Commodifying Effect", in Pattana Kitiarsa (ed.): Religious Commodifications in Asia: Marketing Gods, London, New York: Routledge 2008, p. 124.

${ }^{46}$ Kitiarsa, "Buddha Phanit", p. 127.

47 John Comaroff and Jean L. Comaroff, "Occult Economies and the Violence of Abstraction: Notes from the South African Postcolony", in American Ethnologist 26 (3, 1999): 279-301; JoHN Comaroff and Jean L. Comaroff, "Millennial Capitalism: First Thoughts on a Second Coming", in Public Culture, 12 (2, 2000): p. 291-343.

${ }^{48}$ Kitiarsa, "Buddha Phanit", p. 120-121. 
historical evidence for the client-like relationship between monks and their lay supporters in the early phases of Buddhist monasticism. ${ }^{49}$ Rather than wandering lonely in search of salvation, the early Buddhist monks offered "goods" in terms of services to their lay followers. They "settled in monasteries and became familiar components in the local scene with priest-like functions. This was probably an inevitable process, reaching some kind of mature development about 250 years after the founding of Buddhism." 50

Also speaking against the explanations of the commodification and commercialization of Thai Buddhism as a result of either the state authorities' loosening their control over the sangh $a^{51}$ or as an endemic "postmodern" fragmentation and de-centralization of social space, ${ }^{52}$ Richard $\mathrm{O}^{\prime} \mathrm{Connor}^{53}$ has credibly argued that it was exactly the state-imposed national Buddhism and centralized state control over the sangha in the late nineteenth and early twentieth centuries that alienated people from Buddhism and opened a market for variety of "unorthodox" religious forms. ${ }^{54}$ In brief, "[i]nstead of seeing this commercialization as a modern phenomenon or a sign of the decline of Buddhism, scholars need to take a historical view and attend to 'multiple ethnographies of multiple Buddhisms.'”55

${ }^{49}$ Gregory Schopen, Bones, Stones, and Buddhist Monks: Collected Papers on the Anthropology, Epigraphy, and Texts of Monastic Buddhism in India, Honolulu: University of Hawai'i Press 1997, passim.

${ }^{50}$ Greg Bailey and Ian Mabbett, The Sociology of Early Buddhism, Cambridge: Cambridge University Press 2003, p. 7-8.

${ }^{51}$ Peter A. Jackson, "Withering Centre Flourishing Margins. Buddhism's Changing Political Roles", in Kevin Hewison, (ed.), Political Change in Thailand. Democracy and Participation, London, New York: Routledge 1997, p. 75-93.

52 James TaYlor, "(Post-) Modernity, Remaking Tradition, and the Hybridisation of Thai Buddhism", Anthropological Forum 9 (2, 1999), p. 163-187; JAMEs TAYLOR, "Cyber-Buddhism and Changing Urban Space in Thailand" (online), Space and Culture 6 (3, 2003; accessed May 2016), p. 292-308, available online at http://sac.sagepub.com/cgi/content/abstract/6/3/292.

${ }^{53}$ Richard A. O'Connor, "Interpreting Thai Religious Change: Temples, Sangha Reform and Social Change", Journal of Southeast Asian Studies 24 (2, 1993), p. 330-339.

54 "The other impetus, centralizing Sangha reforms, countered the wat's localism but failed to win control of religion. What it did was turn the laity out of the wat, breaking them out of communities and making them into religious free agents. That created a clientele for today's religious entrepreneurs, lay and monastic alike." O’ConNor, "Interpreting Thai Religious Change”, p. 335.

${ }_{55}$ McDaniel, The Lovelorn Ghost and the Magical Monk, p. 193. The "commercialization" thesis makes also unrealistic presumptions about contemporary Thai Buddhism. Even in its most modest and sober forms, as for example Luang Pō Teean's lineage dismissal of all forms of superstitions, material excesses and distractions from meditation practice, make the concerns of prosperity and well-being part of its rhetoric: "When awareness comes in to know the body and mind, then all things are stopped or 'tamed'. This is the result of being aware of the body and mind. This is the most complete development of life: all suffering disappears, one gains good health and (even) the economy goes better. ... I am not boasting, but since I have been practicing I hardly ever get sick, my health is really excellent. It is because of the improvement of life, and I am looking after it. The Dhamma will protect one. The Dhamma inevitably looks after the practitioner." KAMKEE-AN Suvanno, Watching: Not 'Being': Developing Awareness According to the Practice of Loo-ang Por Tee-an Cittasubho, compiled and translated by Venerable Tone (Tony) Jinavamso (Antoine van der Bom), 2006, p. 168. 
Historical circumstances shape the "commodification of religion" and can make it more or less pronounced, but they do not cause it. An ideology of materially unproductive monastics who are economically dependent on the laity cannot be divorced from the concerns of prosperity or hostile to the production of surplus. ${ }^{56}$ Buddhist monks are a source of magical power (sagsit) and merit (T. bun, บุญ) in which the laity can share, and thus keep the exchange going. The "center-periphery dialectics", to borrow Tambiah's ${ }^{57}$ term for the mutual legitimization of other- and this-worldly orientations in one religious system, is an adaptation, not a mere historical contingency.

Critics of the practices performed at wat Thāmai point out that the originally ethical law of kamma has been turned into a quasi-material substance marketed and manipulated as any other commodity. The roots of this of reification of kamma, however are not a mere rhizome in the soil of post-modern "commodity logic" but go deep into our cognitive structures.

Justin Barrett coined the term "theological correctness" ${ }^{38}$ for multiple representations of religious concepts in single individual. ${ }^{59} \mathrm{He}$ has experimentally demonstrated that subjects who explicitly hold the notion of God as an intangible formless, omnipresent and omnipotent being, in practical everyday situations tend to impose on God human limitations, e.g., serially attending to actions instead of performing them at once. This proclivity of the mind to transform cognitively costly, abstract concepts into more intuitive forms has been explained through the "dual-processing" model of reasoning in which disparate conditions - practical everyday situations on the one hand and reflective times unaffected by real-time exigencies on the other - affect the representations of abstract concepts. In everyday practical situations our mind tends to push abstract concepts towards one of the five ontological categories - the broadest categories into which we organize our perception of the world.

Barrett focuses on anthropomorphism - i.e., the process of attributing human-like characteristics to an abstract concept, approximating thus the ontological category of person. But it is plausible that, when such a move is blocked for conceptual reasons, (as, for example, by the fundamental Buddhist dictum that there is no I, no Self,

${ }^{56}$ See Bailey and Mabbett, The Sociology of Early Buddhism, p. $66 \mathrm{ff}$.

57 Stanley J. Tambiah, The Buddhist saints of the Forest and the Cult of Amulets: A Study in Charisma, Hagiography, Sectarianism, and Millennial Buddhism, Cambridge, New York: Cambridge University Press 1984, p. $183 \mathrm{ff}$.

58 "I propose one may think of religious concepts as lying on the continuum of abstractness or cognitive complexity. Orthodox theological dogma of a tradition or culture (typically) anchors the complex end of the continuum. On the simple or concrete end is naïve intuitive knowledge about things in the world and the causal relationships that govern them. In between these endpoints lie religious concepts as actually represented by individuals and groups of individuals. They range between the two anchors depending on the cognitive demands of a particular context." Justin L. BARRETT, "Theological Correctness: Cognitive Constrains and the Study of Religion”, Method o Theory in the Study of Religion 11 (4, 1999): p. 325. See also Justin L. BARRETT, "Cognitive Constraints on Hindu Concepts of Divine”, Journal for the Scientific Study of Religion 37 (4, 1998): p. 608-619.

59 BARrett, “Theological Correctness", p. 325. 
(P. anatt $\bar{a})$ ) the change will be directed towards one of the four remaining ontological categories - animal, plant, tool, or natural object.

This general human tendency to make abstract religious concepts more intuitive and manipulable in day-to-day situations exists, commercialization or not. ${ }^{60}$ Its understanding helps balance the over-accentuation of concepts like "commodification" in the explanations of religious representations and practices.

The rituals routinely performed at wat Thāmai manipulate impersonal powers. They neutralize, improve (T. gae, แก้) or magically unlock (T. sadt, สะเดาะ) people’s kamma (T. gam, กรรม), bad luck (T. khrø, เคราะห์) or bad-luck-kamma (T. khrøg$a m$, เคราะห์กรรม) rather than interact with intentional agents. This may be ascribed to the fundamental Buddhist anti-agentive conceptual framework based on the central teaching of anattā (no-I, no-Self) which steers the transformation of kamma away from gods, demons, and other intentional agents and towards the direction of impersonal, malleable, inanimate matter.

Explaining these rituals, officiant monks as well as their clients, whether at wat Thāmai or elsewhere, used the terms associated with material substances. Kamma was being diffused, scattered, powdered (T. tham hai gamgrajāi, ทำให้กรรมกระจาย) ${ }^{6}$ Also the precautions taken against bad kamma leaving the body during the ritual indicates that it is represented as a malleable material object rather than a restructured abstract pattern. The term "khrogam" reveals that despite scholars' emphasis on the "ethical", law-like nature of kamma, its popular representation has merged seamlessly with the concepts of amoral powers affecting peoples' lives. ${ }^{62}$ Similar to the concept of "bad luck (T. khro, เคราะห์)" the word "kamma" is used, in the Thai context, mostly in a negative sense, meaning bad kamma. It is a reversion of the values displayed on the banners, posters, and walls of the wat's buildings.

The cultural success of rituals improving ones' existential status will to a large extent depend on the range of situations which the culture attributes to impersonal forces as opposed to individuals' will and acts. In Thai culture the scale is surprisingly wide. An author of a popular book on sadekhro lists these situations as an illustration of "khro understood in broader sense of kamma":

"[S]uffering from a series of unpleasant events, bad health, unexpected spending, losing job and difficulties to find a new one, broken family, misbehaving child, being abandoned by one's spouse, becoming addicted to substances and gambling, becoming a victim of bad temptations, all the things that make your life to sink down." ${ }^{63}$

${ }^{60}$ See also Miloš Hubina, "Preliminaries to the Study of Sadokhro Rituals: How Rituals make People Better Buddhists”, Studia Orientalia Slovaca 16 (1, 2017): p. 43-67.

${ }^{61}$ Monks never used the word "elimination" since the ultimate dealing away with kamma is still the sole prerogative of meditation.

${ }^{62}$ Kitiarsa, among others, notes: "When it is translated into practice, karma is usually perceived as 'karmically determined fate' (khro kam), which guides people to either fortunate or unfortunate ways." Kitiarsa, "Buddha Phanit”, p. 133.

${ }^{63}$ Gaewthāeñ, "Sadekhre”" Duei Ton Ēng Hen Phon Than Tā, Samnak Pim Yōn Rōi 2013, p. 11. 
It seems to me that gambling, addiction to substances, misbehavior of one's children, a broken family, or being abandoned by one's spouse, would, in a Western context, only be attributed to external, impersonal conditions with great difficulties. The elements of personal responsibility (though not necessarily that of the victim, and accompanied by recognition of social contributors) would prevail over "circumstances" or "powers".

I am unaware of a comparative study on agency attribution ${ }^{64}$ but Nisbet $e t$ al ${ }^{25}$ concepts of "holistic thought" 66 and "field dependence" developed in the context of comparative studies of East Asians might be relevant also in this cultural area. The concepts refer to the heightened attention paid to the context or "field" among East Asians when compared to Americans. Presenting a body of evidence for the phenomenon in both perceptual and reasoning processes, Nisbett $e t$ al have further proposed that "[i]t seems reasonable to assume that people attribute causality to the events they attend to. If Westerners attend to the object, we would expect them to attribute causality to the object. If East Asians attend to the field and the object's relations with the field, it seems likely that they would be more inclined to attribute causality to context and situations. Each of these expectations is supported by a substantial amount of evidence. ${ }^{167}$ A virtually unlimited net of causal links makes the field an under-determined area where "anything goes". An interesting question then is whether the "high contingency quotient" reported by Spiro ${ }^{68}$ among the Burmese, ${ }^{69}$ "tolerance for ambiguity", "flexibility and adjustment orientation", and "flexibility over principle and ideology" identified by Komin among the Thais might indicate the influence of the same oversaturated background which permits a much greater share of uncontrolled post-hoc interpretation and causal attribution, and less prediction, long-term planning, and personal responsibility.

${ }^{64}$ Though Barrett refers to a specific "agent-centered social cognition of American adults". Justin L. BARRETT, "Bringing Data to Mind: Empirical Claims of Lawson and McCauley's Theory of Religious Ritual”, in T. Light and B. C. Wilson (eds.), Religion as a Human Capacity: A Festschrift in Honor of E. Thomas Lawson, Leiden, Boston: Brill 2004, p. 284.

${ }^{65}$ Richard E. Nisbett, Kaiping Peng, Incheol Choi and Ara Norenzayan, "Culture and Systems of Thought: Holistic Versus Analytic Cognition”, Psychological Review 108 (2, 2001): p. 291-310.

${ }^{66}$ Nisbett et al define "holistic thought" as "involving an orientation to the context or field as a whole, including attention to relationships between a focal object and the field, and a preference for explaining and predicting events on the basis of such relationships. Holistic approaches rely on experience-based knowledge rather than on abstract logic and are dialectical, meaning that there is an emphasis on change, recognition of contradiction and of the need for multiple perspectives, and a search for the "Middle Way" between opposing propositions. Nisbett et al., "Culture and Systems of Thought”, p. 293.

${ }^{67}$ Nisbett et al., "Culture and Systems of Thought", p. 298.

${ }^{68}$ Melford E. Spiro, Buddhism and Society: A Great Tradition and its Burmese Vicissitudes, Second expanded edition, Berkeley: University of California 1982 (first published 1970), p. 89.

69 "Almost invariably, the answer to any question concerning a villager's habits, his likes and dislikes ... or almost anything else, concludes with such common refrains as: 'That is the way I feel now, but I can't tell about the future,' ... The Burmese view not only their own inner states as evanescent but look upon interpersonal relationships in the same manner." SPIRo, Buddhism and Society, p. 89-90. 


\section{Summation}

I have argued against productivity of interpreting living Buddhism through the prism of doctrinal tradition and made a case for its understanding as an extension of established cultural practices. As a part of a culture, living Buddhism is based in its system of values and, as with all cultures, constrained by our general cognitive mechanisms. "Buddhism" in such a context is a taxonomical rather than essentialist category identifiable, rather than definable through specific doctrinal concepts.

This outlook is minor in Theravāda studies dominated by socio-cultural paradigm and the theories of syncretism which "rest on the assumption that there is one thing that can be described as pure Brahmanism or Theravada that has been polluted, diluted, or borrowed." ${ }^{70}$

McDaniel's alternative to this model is flawed by its disregard for the psychological embedding of the surrounding culture. I have suggested three corrections, which altogether entail the necessity of integrating socio-cultural and cognitive studies of religion. This integration balances a possible over-accentuation of either cultural or cognitive concepts in explaining religious phenomena. Cognitive and other psychological studies can also provide a causal explanation for socio-cultural models. The force with which "animistic" traditions in Southeast Asia erode the better institutionalized Buddhism and the ease with which practices incongruent with basic Buddhist notions take roots in it can be ascribed to the general human tendency to spontaneously modify abstract concepts into more intuitive forms via approximating one of the ontological categories. The same tendency can be used to explain reification of kamma and its ritualistic manipulation which in traditional socio-cultural studies are typically attributed to (post-) modern "commodity logic" or "fragmentation and de-centralization of social space".

Throughout the text I understood the cognitive constraints as the broadest and most stable framework nesting cultural structures. I don't mean to imply a rigid "stratigraphic" vil view here and I recognize the possibility of cultural structures' offsetting the cognitive constraints.

These complex cultural, cognitive, and environmental structures create a "stabilizing dint" for religious phenomena. I have explained how the similarity of novel practices with the established routines and notions may increase the probability of their recall and thus increase their chances in cultural competition. Similarity of course is not the only way novel phenomena can become stabilized. The study of the nature and functioning of the stabilizing dint is only in its nascent phase and though much of my proposal remains speculative, it is a kind of speculation which, unlike self-contained socio-cultural interpretations, permits empirical testing.

${ }^{70}$ McDAniel, The Lovelorn Ghost and the Magical Monk, p. 15.

${ }^{71}$ Armin W. Geertz, "The Meaningful Brain: Clifford Geertz and the Cognitive Science of Culture”, in Dimitris Xygalatas and William W. McCorkle (eds.), Mental Culture: Classical Social Theory and the Cognitive Science of Religion, Durham: Acumen 2013, p. 178; Clifford GeERTZ, The Interpretation of Cultures, New York: Basic Books 1973, p. $37 \mathrm{ff}$. 
I have illustrated my proposals through the example of a famous Thai wat - wat Thāmai. De-emphasis of the doctrine in my account impacted upon the way I suggest seeing the effigies, visuals, and architecture of the wat. Instead of being symbolic expressions of doctrinal tenets, they have, in real people's representations, an advertising and ritualistic function.

\section{REFERENCES}

THAI REFERENCES:

GAEWTHĀRĀ, "Sadekhre” Duei Ton Ēng Hen Phon Than Tā, Samnak Pim Yōn Rōi 2013. (แก้วธารา, “สะเดาะเคราะห์” ด้วยตนเอง เห็นผลทันตา, สำนักพิมพ์ย้อนรอย 2013.)

SAWATPHĀNIT, Gē, Lagsana Sanghom Thai, in Phanēk Isara Sangkom Vithaiā Lae Mānusaiavithaiā Mahāvithaiālai Thammasāt, Rāingān Gān Sammanā Thāng Vichāgān Ruang Lagsana Sangkhom Thai, HJG. Gān Phim Phranakhon, 1979.

(สวัสดิ์พาณิชย์, ก่อ, ลักษณะสังคมไทย, in แผนกอิสระสังคมวิทยาและมานุษยวิทยา มหาวิทยาลัย ธรรมศาสตร์, รายงานการสัมมนาทางวิชาการ เรื่อง ลักษณะสังคมไทย, หจก. การพิมพ์พระนคร 1979.)

KHRUAGAEW NA LAMPHŪN, PHAITHUN, Lagsana Sangkom Thai, Nāi Yōt Ying Sōphon Phū Phim Phū Khōsanā1975 .

(ไพฑูรย์ เครือแก้ว ณ ลำพูน, ลักษณะสังคมไทย, นายยอดยิ่ง โสภน ผู้พิมพ์ผู้โมษณา 1975.)

SUTTHIPAN, S., Gae Gam Phon Thuk Ānisong Haeng Satthā Jāk Luang Pū Rung Thtung Phra Ājān Uthēn, Borisat Sathāpon Buk Jamgat 2009.

(สุทธิพันธ์, ส., แก้กรรม พ้นทุกข์ อานิสงส์แห่งศรัทธา จากหลวงปู่รุ่งถึงพระอาจารย์อุเทน, บริษัท สถาพรบุ๊คส์ จำกัด 2009.)

\section{ENGLISH REFERENCES:}

Atran, ScotT, In Gods We Trust: The Evolutionary Landscape of Religion, New York: Oxford University Press 2004, 400 p.

Bailey, Greg, and Ian Mabbett, The Sociology of Early Buddhism, Cambridge: Cambridge University Press 2003, 284 p.

BARrett, Justin L., "Cognitive Constraints on Hindu Concepts of Divine”, Journal for the Scientific Study of Religion 37 (4, 1998): p. 608-619.

BARrett, Justin L., "Theological Correctness: Cognitive Constrains and the Study of Religion”, Method \& Theory in the Study of Religion 11 (4, 1999): p. 325-339.

BARrett, Justin L., "Bringing Data to Mind: Empirical Claims of Lawson and McCauley's Theory of Religious Ritual", in T. Light and B. C. Wilson (eds.), Religion as a Human Capacity: A Festschrift in Honor of E. Thomas Lawson, Leiden, Boston: Brill 2004, p. 265-288.

BARREtT, NATHANIEL F., “Toward an Alternative Evolutionary Theory of Religion: Looking Past Computational Evolutionary Psychology to a Wider Field of Possibilities", Journal of the American Academy of Religion 78 (3, 2010): p. 583-621.

Boddнi, Bнiккнu, The Numerical Discourses of the Buddha: A Translation of the Anguttara Nikaya, Boston: Wisdom Publications 2012, 1924 p.

Boyer, Pascal, “Cognitive Aspects of Religious Symbolism”, in Pascal Boyer (ed.), Cognitive Aspects of Religious Symbolism, Cambridge, New York: Cambridge University Press 1993, p. 4-47.

Boyer, Pascal, and Charles Ramble, "Cognitive Templates for Religious Concepts: Cross-cultural Evidence for Recall of Counter-intuitive Representations", Cognitive Science 25 (2001): p. 535-564. 
Boyer, Pascal, Religion Explained: The Evolutionary Origins of Religious Thought, New York: Basic Books 2001, 375 p.

Boyer, Pascal, The Fracture of an Illusion: Science and the Dissolution of Religion, Götingen: Vandenhoeck \& Ruprecht 2011, 112 p.

Boyer, Pascal, The Naturalness of Religious Ideas: A Cognitive Theory of Religion, Berkeley: University of California Press 1994, 324 p.

BrekKe, Torkel, Religious Motivation and the Origins of Buddhism: A Social-Psychological Exploration of the Origins of a World Religion, London, New York: Routledge 2002, $150 \mathrm{p}$.

Connors, Michael K., Democracy and National Identity in Thailand, New York, London: RoutledgeCurzon 2005, first published 2003, 275 p.

Cook, Joanna, Meditation in Modern Buddhism: Renunciation and Change in Thai Monastic Life, Cambridge, New York: Cambridge University Press 2010, 214 p.

Comaroff, John, and Jean L. Comaroff, Occult Economies and the Violence of Abstraction: Notes from the South African Postcolony, in American Ethnologist 26 (3, 1999): 279-301.

Comaroff, John, and Jean L. Comaroff, Millennial Capitalism: First Thoughts on a Second Coming, in Public Culture, 12 (2, 2000): 291-343.

D'Andrade, Roy G., "Schemas and Motivations", in Roy G. D'Andrade and Claudia Strauss (eds.), Human motives and Cultural Models, Cambridge: Cambridge University Press 1997 (first published 1992), p. 23-44.

Engel, David M., and Jaruwan D. Engel, Tort, Custom, and Karma: Globalization and Legal Consciousness in Thailand, Stanford: Stanford University Press 2010, 190 p.

Evans, Jonathan S., "Dual-Processing Accounts of Reasoning, Judgment, and Social Cognition", in Annual Review of Psychology, 59 (2008): p. 255-278.

Geertz, Armin W., “The Meaningful Brain: Clifford Geertz and the Cognitive Science of Culture", in Dimitris Xygalatas and William W. McCorkle (eds.), Mental Culture: Classical Social Theory and the Cognitive Science of Religion, Durham: Acumen 2013, p. 176-196.

Geertz, Clifford, The Interpretation of Cultures, New York: Basic Books 1973, 470 p.

“Global Peace Index 2016” (online), Institute for economics and Peace, accessed June 2016, available online at http://static.visionofhumanity.org/sites/default/files/GPI\%20 2016\%20Report_2.pdf.

GOMBRICH, RICHARD, “Recovering the Buddha's Message”, Buddhist Forum (1), London: SOAS 1990, p. 5-20.

Gombrich, Richard, How Buddhism Began: The Conditioned Genesis of the Early Teachings, London, New York: Routledge 2006 (first published 1996), 180 p.

Gombrich, RICHARD: Theravāda Buddhism: A social History from Ancient Benares to Modern Colombo, London, New York: Routledge 1988, 237 p.

Haidt, Jonathan, The Righteous Mind: Why Good People are Divided by Politics and Religion, New York: Vintage 2012, 528 p.

Hanks, Lucien M., JR., "Merit and Power in the Thai Social Order", American Anthropologist New Series 64 (6, 1962): p. 1247-1261.

Holt, Clifford, Spirits of Place: Buddhism and Lao Religious Culture, Honolulu: University of Hawaii 2009, $348 \mathrm{p}$.

Hubina, Miloš, "Preliminaries to the Study of Sadekhro Rituals: How Rituals make People Better Buddhists”, Studia Orientalia Slovaca 16 (1, 2017): p. 43-67.

Jackson, Peter A., "Withering Centre Flourishing Margins. Buddhism's Changing Political Roles", in Kevin Hewison (ed.), Political Change in Thailand. Democracy and Participation, London, New York: Routledge 1997, p. 75-93. 
Jensen, Jeppe S., "Framing Religious Narrative: Cognition and Culture Theoretically", in Armin W. Geertz and Jeppe S. Jensen (eds.), Religious Narrative, Cognition and Culture: Image and Word in the Mind of Narrative, London, Oakville: Equinox 2011, $336 \mathrm{p}$.

KamkeE-An Suvanno, Watching: Not 'Being': Developing Awareness According to the Practice of Loo-ang Por Tee-an Cittasubho, compiled and translated by Venerable Tone (Tony) Jinavamso (Antoine van der Bom), 2006.

Kirsch, Thomas A., "Complexity of Thai Religious System", The Journal of Asian Studies $36(2,1977):$ p. $241-266$.

Kitiarsa, Pattana, "Beyond Syncretism: Hybridization of Popular Religion in Contemporary Thailand”, Journal of Southeast Asian Studies 36 (3, 2005): p. 461-487.

Kitiarsa, Pattana, "Buddha Phanit: Thailand's Prosperity Religion and its Commodifying Effect”, in Pattana Kitiarsa (ed.): Religious Commodifications in Asia: Marketing Gods, London, New York: Routledge 2008, p. 120-143.

Kitiarsa, Pattana, Mediums, Monks, and Amulets: Thai Popular Buddhism Today, Chiang Mai: Silkworm Books 2012, 170 p.

Komin, Suntaree, Psychology of Thai People: Values and Behavioral Patterns, Bangkok: NIDA 1990, 359 p.

Kumer, Hans, "Causal Knowledge in Animals", in Dan Sperber, David Premack and Ann J. Premack, Causal Cognition: A Multidisciplinary Debate, Oxford: Clarendon Press, New York: Oxford University Press 2002 (first published 1995), p. $26-36$.

LANGER, RitA, Buddhist Rituals of Death and Rebirth: Contemporary Sri Lankan Practice and its Origins, London, New York: Routledge 2007, 243 p.

Lawson, Thomas, "Explanatory Pluralism and the Cognitive Science of Religion", in Dmitris Xygalatas and William W. McCorkle Jr. (eds.), Mental Culture: Classical Social Theory and the Cognitive Science of Religion, Durham: Acumen 2013, p. 11-32.

Masuda, T., and R. E. Nisbet, Culture and Attention to Object vs. Field, unpublished manuscript, University of Michigan 2001.

Matics, K. I., Gestures of the Buddha, Bangkok: Chulalongkorn University Press 2004, $295 \mathrm{p}$.

McDaniel, Justin T., "Buddhism in Thailand: Negotiating the Modern Age", in Stephen C. Berkwitz (ed.), Buddhism in World Cultures: Comparative Perspectives, Santa Barbara: ABC-CLIO 2006, p. 101-128.

McDaniel, Justin T., “The Agency between Images: The Relationship among Ghosts, Corpses, Monks, and Deities at a Buddhist Monastery in Thailand", a talk given at the International Conference: Buddhist Narrative in Asia and Beyond, 9-11 August 2010, Bangkok Thailand (transcript).

McDaniel, Justin T., Gathering Leaves \& Lifting Words: Histories of Buddhist Monastic Education in Laos and Thailand, Seattle: University of Washington Press 2008, 358 p.

McDaniel, Justin T., The Lovelorn Ghost and the Magical Monk, New York: Columbia University Press 2011, $327 \mathrm{p}$.

McDermott, James P., "Sādhīna Jātaka: A Case against the Transfer of Merit", Journal of the American Oriental Society 94 (3, 1974): p. 385-387.

McDermott, James P., Development in the Early Buddhist Concept of Kama/Karma, New Delhi: Munshiram Manoharlal Publishers Pvt. Ltd. 2003 (first published 1984), $185 \mathrm{p}$.

Mole, Robert L., Thai Values and Behavior Patterns, Rutland: Charles E. Tuttle Company 1973, $182 \mathrm{p}$. 
Morris, Brian, Religion and Anthropology, New York: Cambridge University Press 2006, $350 \mathrm{p}$.

Mulder, Niels, Everyday Life in Thailand: An Interpretation, Bangkok: Duang Kamol $1979,223 \mathrm{p}$.

Mulder, Niels, Inside Southeast Asia. Thai Javanese and Filipino Interpretations of Everyday Life, Bangkok: Duang Kamol 1992, 178 p.

MÜLlER, MARION G., "Iconography and Iconology as a Visual Method and Approach", in Eric Margolis and Luc Pauwels (eds.), The Sage Handbook of Visual Research Methods, Los Angeles: Sage Publications Ltd. 2011, p. 283-297.

Nisbett, Richard E., Kaiping Peng, Incheol Choi and Ara Norenzayan, "Culture and Systems of Thought: Holistic Versus Analytic Cognition”, Psychological Review 108 (2, 2001): p. 291-310.

Norris, Pippa, and Ronald Inglehart, Sacred and Secular: Religion and Politics Worldwide, Cambridge, New York: Cambridge University Press 2004, 329 p.

O'Connor, Richard A., "Centers of Sanctities, Regions and Religion: Varieties of Thai Buddhism”, communication at the Annual Meeting of the American Anthropological Association, Washington D.C. 1985, 26 p.

O'Connor, Richard A., "Interpreting Thai Religious Change: Temples, Sangha Reform and Social Change", Journal of Southeast Asian Studies 24 (2, 1993), p. 330-339.

Obeysekere, Gananath, "The Great Tradition and the Little”, The Journal of Asian Studies 22 (2, 1963): p. 139-153.

Obeysekere, Gananath, Imagining Karma: Ethical Transformation in Amerindian, Buddhist, and Greek Rebirth, Berkeley: University of California Press 2002, 448 p.

Ockey, James, Making Democracy: Leadership, Class, Genders, and Political Participation in Thailand, Chiang Mai: Silkworm Books 2004, 244 p.

Paden, William E., "Connecting with Evolutionary Models", in Villi Braun and Russell T. MCCutcheon (eds.), Introducing Religion: Essays in Honor of Jonathan Z. Smith, London, Oakville: Equinox Publishing 2008, p. 416-417.

Paden, William E., "The Prestige of the Gods: Evolutionary Continuities in the Formation of Sacred Objects", in Armin W. GeErtz (ed.), Origins of Religion, Cognition and Culture, Durham: Acumen 2013, p. 82-97.

Paden, William E., New Patterns for Comparative Religion: Passages to an Evolutionary Perspective, London, New York: Bloomsbury Academic 2016, 253 p.

Pemaratana, Soorakkulame, "Evolution of the Theravāda Buddhist Idea of 'Merittransference' to the Dead, and its Role in Sri Lankan Buddhist Culture", Buddhist Studies Review 30 (1, 2013): p. 89-112.

Pichard, Pierre, "The Thai Monastery”, in Pierre Pichard and François Lagirarde (eds.), The Buddhist Monastery: A Cross-Cultural Survey, Paris: École française d'extrême-orient 2003, p. 93-118.

PyysiäInen, Ilka, How Religion Works: Towards and New Cognitive Science of Religion, Leiden, Boston: Brill 2003, 272 p.

PyysiäInen, ILKa, Supernatural Agents: Why We Believe in Souls, Gods, and Buddhas, Oxford, New York: Oxford University Press 2009, 285 p.

Richerson, Peter J., and Robert Boyd, Not by Genes Alone: How Culture Transforms Human Evolution, The University of Chicago Press 2006 (first published 2005), 332 p.

Ridley, Matt, The Origins of Virtue: Human Instincts and the Evolution of Cooperation, Penguin Books 1996, 297 p.

Schopen, Gregory, Bones, Stones, and Buddhist Monks: Collected Papers on the Anthropology, Epigraphy, and Texts of Monastic Buddhism in India, Honolulu: University of Hawai'i Press 1997, 297 p. 
Schwartz, Shalom H., "Basic human values: Their content and structure across countries”, in A. TAMAYo and J. B. Porto (eds.), Valores e comportamento nas organizações, Petrópolis: Vozes 2005, p. 21-55.

Schwartz, Shalom H., "Universals in the Content and Structure of Values: Theoretical Advances and Empirical Tests in 20 Countries" (online), Advances in Experimental Social Psychology 25 (1992), accessed May 2016, available online at http://kodu.ut.ee/ cect/teoreetiline\%20seminar\%2023.04.2013/Schwartz\%201992 .pdf.

Simpson, Andrew, and Noi Thammasathien, "Laos and Thailand", in Andrew Simpson (ed.), Language and National Identity in Asia, Oxford, New York: Oxford University Press 2007, p. 391-414.

Sørensen, Jesper, "Charisma, Tradition, and Ritual: A Cognitive Approach to Magical Agency”, in Harvey Whitehouse and Robert M. McCauley (eds.), Mind and Religion. Psychological and Cognitive Foundations of religion, Lanham: Altamira Press 2005, p. 167-186.

Sørensen, Jesper, "Religion, Evolution, and the Immunology of Cultural Systems", Evolution and Cognition 210 (1, 2004): p. 61-73.

Sørensen, Jesper, A Cognitive Theory of Magic, Lanham: Altamira Press 2007, 218 p.

Sperber, Dan, "Apparently Irrational Beliefs", in Martin Hollis and Steven Lukes (eds.), Rationality and Relativism, Oxford: Blackwell Publishers 1993 (first published 1983), p. 149-180.

Sperber, DAn, Rethinking Symbolism, Cambridge, New York: Cambridge University Press 1975,153 p.

Spiro, Melford E., "Religion: Problems of definition and Explanation”, in MiChael BAnton (ed.), Anthropological Approaches to the Study of Religion, London, New York: Routledge 2004 (first published 1966), p. 85-126.

Spiro, Melford E., Buddhism and Society: A Great Tradition and its Burmese Vicissitudes, Second expanded edition, Berkeley: University of California 1982 (first published 1970), $510 \mathrm{p}$.

SweArer, Donald K., Becoming the Buddha: The ritual of Image Consecration in Thailand, Delhi: Motilal Banarsidass 2004.

Talmont-Kaminski, KonRad, Religion as Magical Ideology: How the Supernatural Reflects Rationality, Durham: Acumen 2013, 160 p.

Tambiah, Stanley J., Buddhism and the Spirit Cults in North-east Thailand, Cambridge University Press 1970, 388 p.

Tambiah, Stanley J., The Buddhist saints of the Forest and the Cult of Amulets: A Study in Charisma, hagiography, Sectarianism, and Millennial Buddhism, Cambridge, New York: Cambridge University Press 1984, 417 p.

Taylor, James, "(Post-) Modernity, Remaking Tradition, and the Hybridisation of Thai Buddhism”, Anthropological Forum 9 (2, 1999): p. 163-187.

Taylor, James, “Cyber-Buddhism and Changing Urban Space in Thailand” (online), Space and Culture 6 (3, 2003; accessed May 2016), p. 292-308, available online at http://sac.sagepub.com/cgi/content/abstract/6/3/292.

TAYlor, James, “Understanding Social Realities: Stanley Tambiah's Early Contribution to Sociology of Thai Buddhism", in Felicity Aulino, Miriam Goheen and Stanley J. ТАмвiaн (eds.), Radical Egalitarianism: Local Realities, Global Relations, New York: Fordham University Press 2013, p. 51-67.

Terwiel, Barend J., "A Model for the Study of Thai Buddhism”, The Journal of Asian Studies 35 (3, 1976): p. 391-403. 
Terwiel, Barend J., Monks and Magic: An Analysis of Religious Ceremonies in Central Thailand, Third Revised edition, Bangkok: White Lotus 1994 (first published 1975), $302 \mathrm{p}$.

Thānissaro, The Buddhist Monastic Code: The PātimokkhaTraining Rules Translated and Explained, The Mahāmaḳuta Educational Council 1993.

Turner, LÉon, "Introduction: Pluralism and Complexity in the Evolutionary Cognitive Science of Religion", in Fraser Watts and LÉon Turner, Evolution Religion and Cognitive Science. Critical and Constrictive Essays, Oxford: Oxford University Press 2014, p. 1-20.

“The Twelve Thai Values” (online), Ministry of Natural Resources and Environment, accessed February 2016, available online at http://www.mnre.go.th/ewt_news .php?nid=3230.

Whitehouse, Harvey, "Modes of Religiosity: Towards a Cognitive Explanation of the Sociopolitical Dynamics of Religion”, Method \& Theory in the Study of Religion 14 (2002): p. 293-315.

Wilson, David A., Politics in Thailand, Ithaca: Cornell University Press 1967, 307 p.

Wilson, David Sloan, Darwin's Cathedral: Evolution, Religion, and the Nature of Society, Chicago: The University of Chicago Press 2002, 268 p.

Wittgenstein, Ludwig, Philosophical Occasions 1912-1951, edited by James Klagge and Alfred Nordman, Indianapolis: Hackett Publishing 1993, p. 193.

Xygalatas, Dimitris, and McCorkle, William W. (eds.), Mental Culture: Classical Social Theory and the Cognitive Science of Religion, Durham: Acumen 2013, 268 p. 


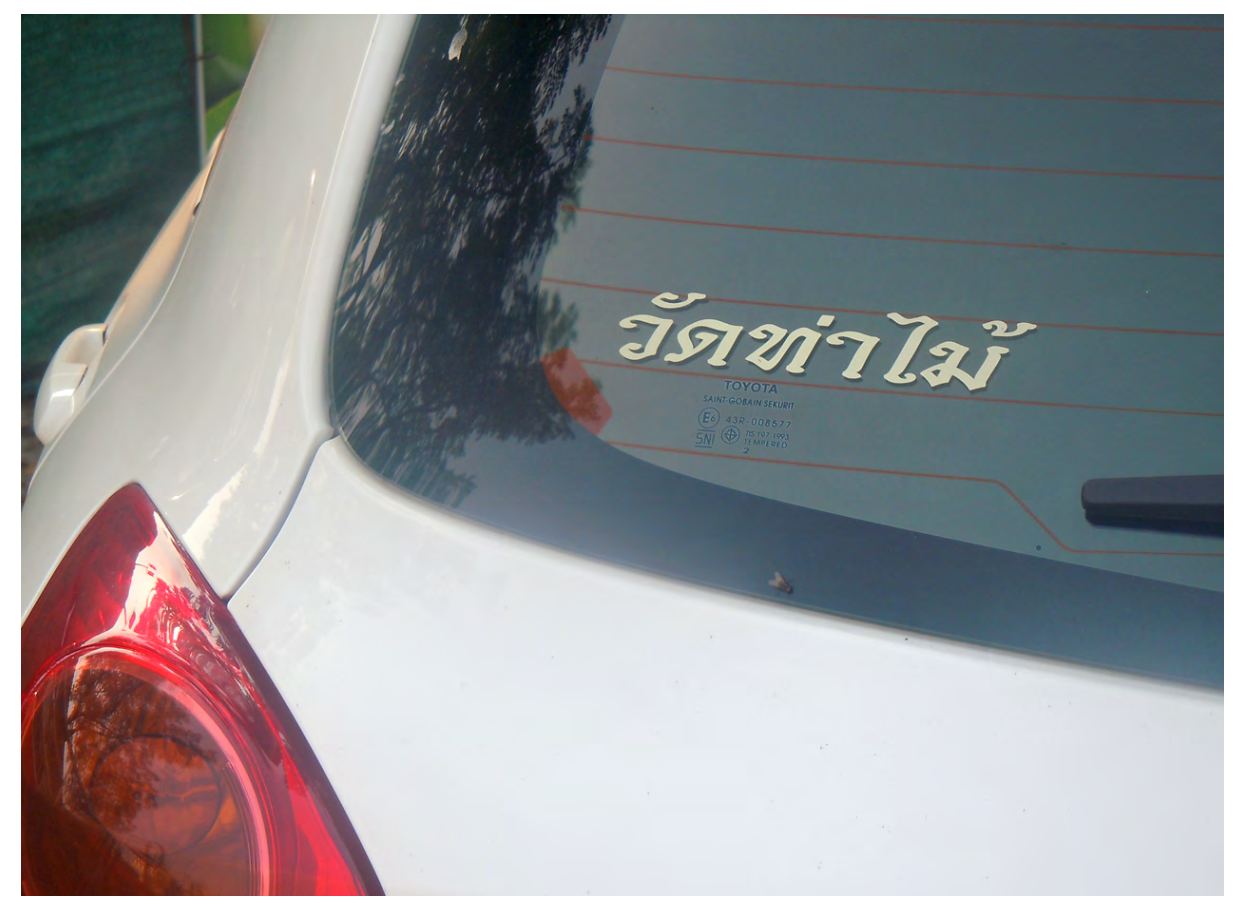

Picture 1

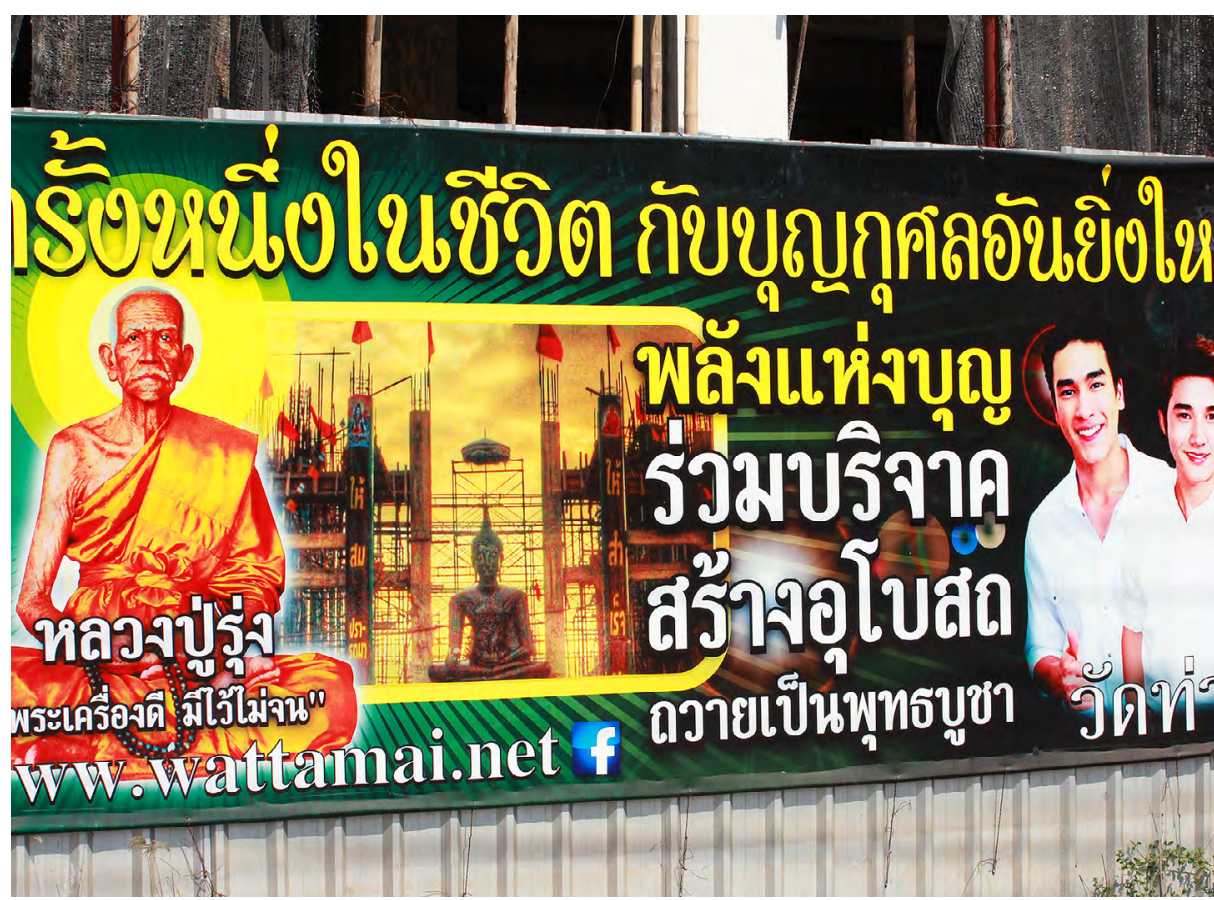

Picture 2 


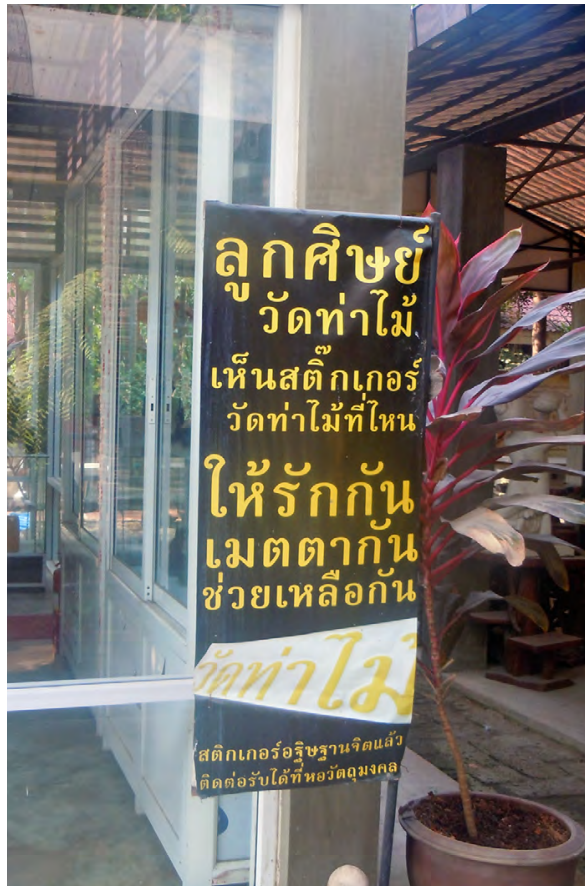

Picture 3

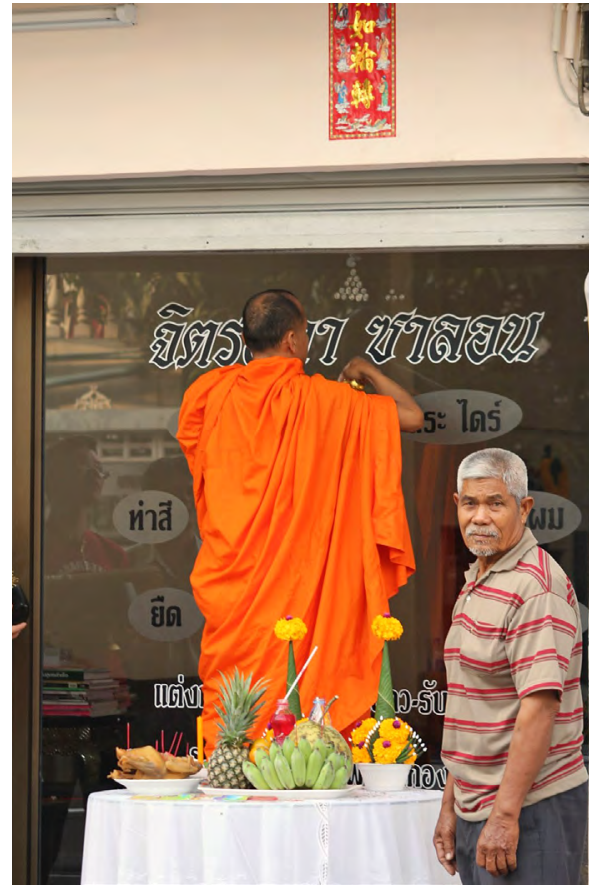

Picture 4

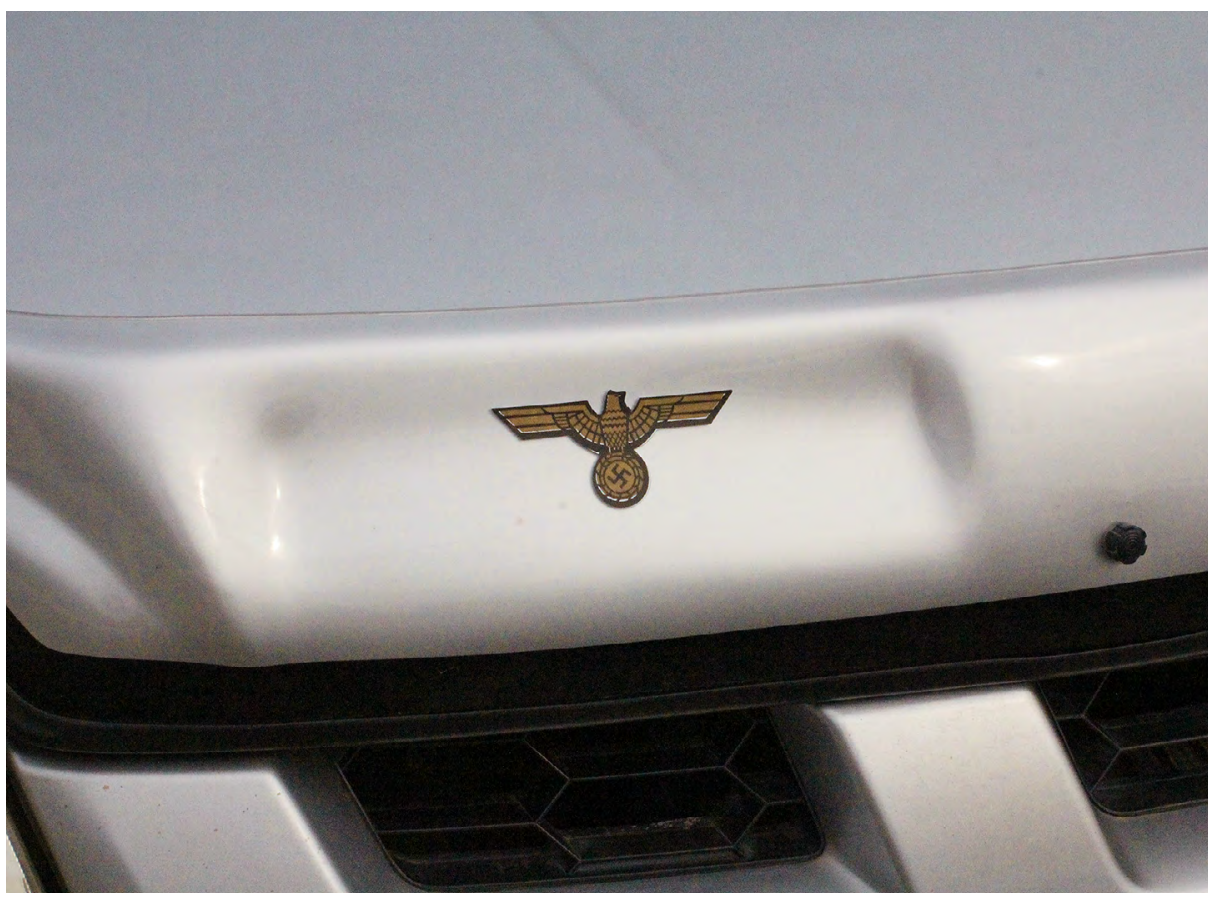

Picture 5 


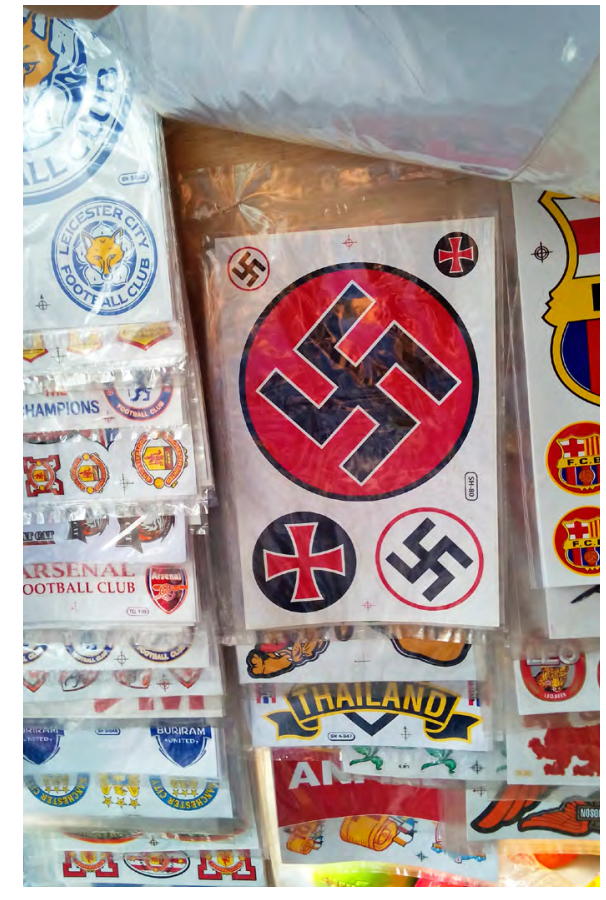

Picture $5 a$

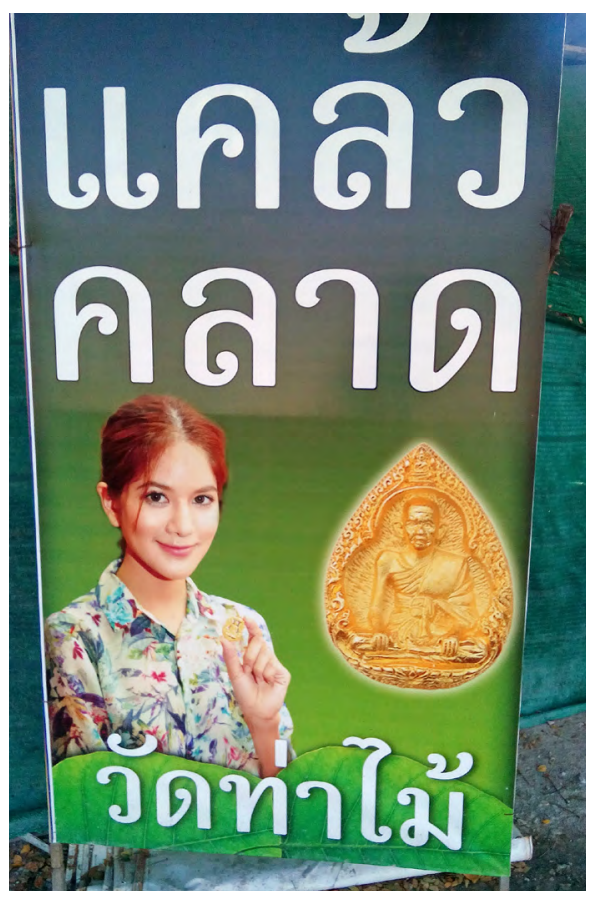

Picture 7

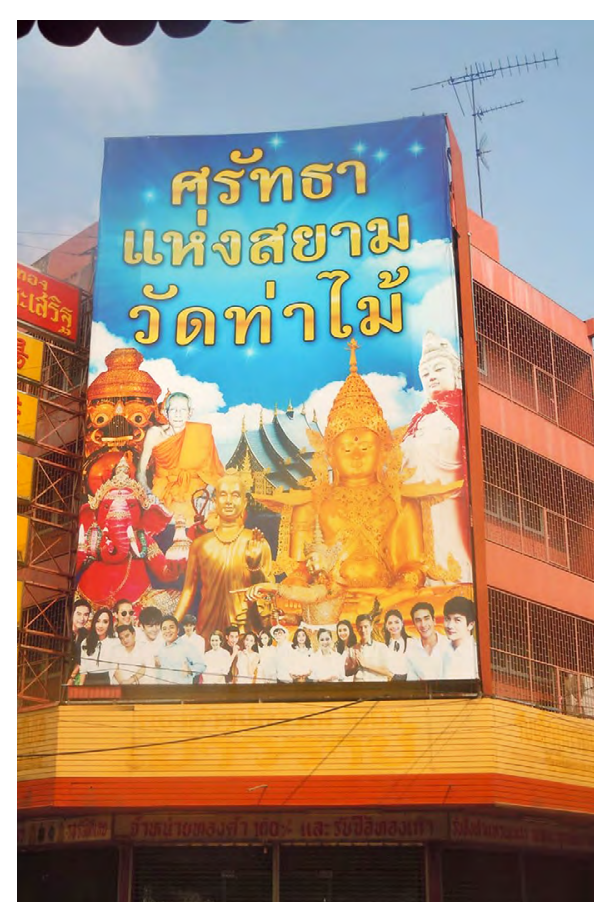

Picture 6

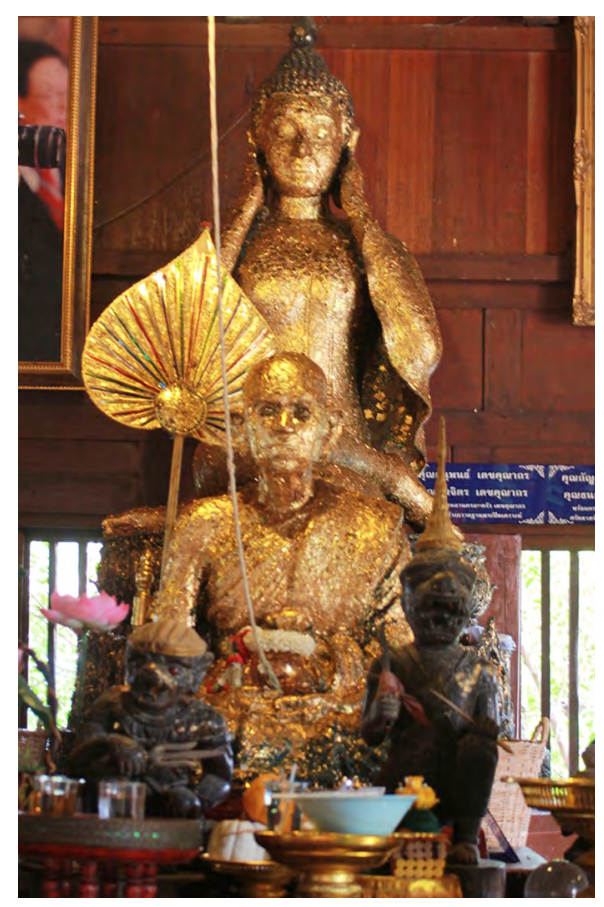

Picture 8 